\title{
Attitudes of inhabitants living in the vicinity of railroads on the matter of trespassing on the railway
}

\author{
Pavlína Skládanáa, Pavel Skládanýa, Pavel Tučka ${ }^{a}$ \\ ${ }^{a}$ Transport Research Center, Líšeňská 2657/33a, Brno-Líšeň 636 00, Czech Republic
}

ABSTRACT: Trespassing on the railway is a very frequent behavior in the Czech Republic, resulting in approximately 200 deaths annually caused by trainperson collisions. This paper studies the attitudes of citizens living near railways and in the immediate vicinity of one of the many illegal shortcuts. The objective of the survey was primarily to acquire information about factors contributing to decisions by various groups of residents to use or not to use an illegal shortcut. This information may be taken as a basis for implementing preventive measures, and in particular those of an awareness-raising character.

The survey involved a total of 619 standardized face-to-face interviews conducted at 26 locations where an illegal shortcut occurs. Eighty-three percent of the respondents were aware that an illegal shortcut existed in the vicinity of their homes, and most were able also to describe its purpose, frequency of use, and typical users. Half of them use such shortcut themselves. The predominant reason for not using the shortcut was the absence of need, that is, it was not on their route (74\%). Thirty-five percent perceived crossing the railway in the given spot as too dangerous, $7 \%$ as inconvenient, and 9\% stated its illegality as the reason. Four percent of respondents who did not use the shortcut stated they feared being fined. Respondents who used the shortcut most frequently provided shortening a journey (85\%) and habit (25\%) as their reasons for doing so. Thirty percent of users feel worried when crossing - predominantly from fear of being hit by a train, less so because they might be fined.

Answers to questions concerning general knowledge suggest the direction that awareness-raising should take. Almost 30\% of the respondents believed they could cross the rails at practically any place so long as there was no sign with an explicit prohibition or a fence. Fifty-four percent considered crossing the rails to be safe if they look around first, and 70\% claimed that a train can be heard well from far away. Estimates as to the numbers of victims of train-person collisions in the previous year were correct in 27\% of the answers, while 53\% of respondents estimated lower numbers and $20 \%$ estimated higher.

KEYWORDS: Railway trespassing; safety; risks; population attitudes

\section{INTRODUCTION}

\subsection{Situation in the Czech Republic}

In the Czech Republic, railway trespassing is a considerable safety problem. Train-person collisions caused by such trespassing claim about 200 victims (ca $20 \%$ of women and $80 \%$ of men) annually (Figure 1). Even though this number includes also the consequences of suicides (approximately 35\% according to estimation of Rail Safety Inspection Office), a large part of the accidents can be ascribed to the regular use of illegal shortcuts. The occurrence of accidents in the areas of such shortcuts is apparent, as can be observed on the map of train-person collisions during 2005-2014 (Fig. 2), created as part of the AMELIA research project (Skládaná et al., 2017).

\subsection{Current state of knowledge from Czech and foreign research}

In the Czech Republic, railway trespassing is a very frequent and, at first view, socially tolerated breach of Act No. 266/1994 Coll., on Railways, Section 4a on Railroad Protection. It happens on all categories of railways. Illegal shortcuts most frequently occur in places of natural pedestrian connections where there is no legal alternative or the alternatives are inconvenient for pedestrians due to various reasons. There are also other reasons for entering the railway. The AMELIA project (Skládaná et al., 2017, see 
Train-person collisions in the Czech Republic during 2007-2017

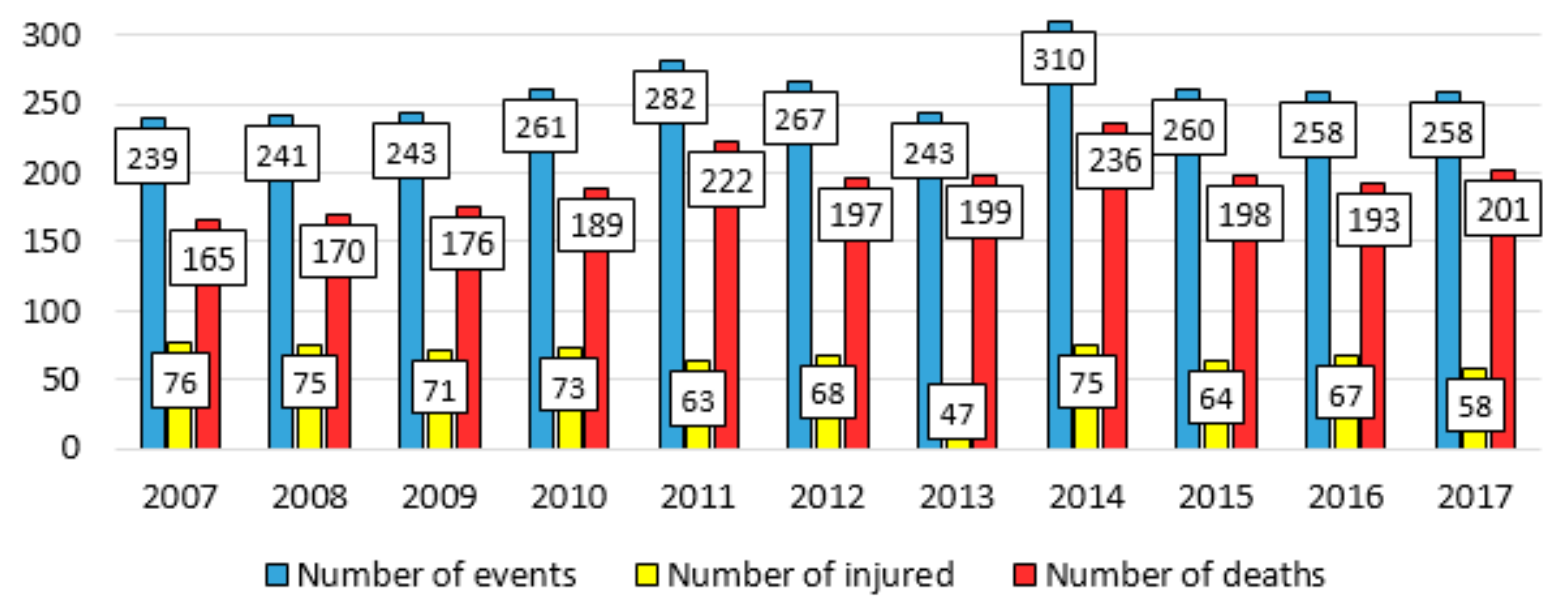

Figure 1. Train-person collisions and their consequences, Czech Republic 2007-2017 (Source: Rail Safety Inspection Office) Source: Rail Safety Inspection Office

https://amelia.cdvinfo.cz/) distinguished six basic types of trespassing locations:

- Stations and stops

- Everyday shortcuts not including stations and stops

- Hiking trails and recreation areas

- Destinations of specific-interest groups

- Places to meet and live

- Railway crossings

In addition to differing by their settings, the individual types vary in particular as to the main cause for trespassing (i.e., the motivation for entering the railway). Railway trespassing at stations and stops as well as at everyday shortcuts, for example, most frequently results from an absence of, unsuitably placed, or difficult-to-navigate legal pedestrian infrastructure. The case of recreation areas is similar, albeit with certain specific features whereby the railway can itself be used directly for recreational purposes (Figure 3). In places that are destinations for special-interest groups (railway fans, urban explorers, graffiti artists), the railway is the destination and not an obstacle. When a railway constitutes a place to live, that represents more of a social problem. Railway crossings are a special

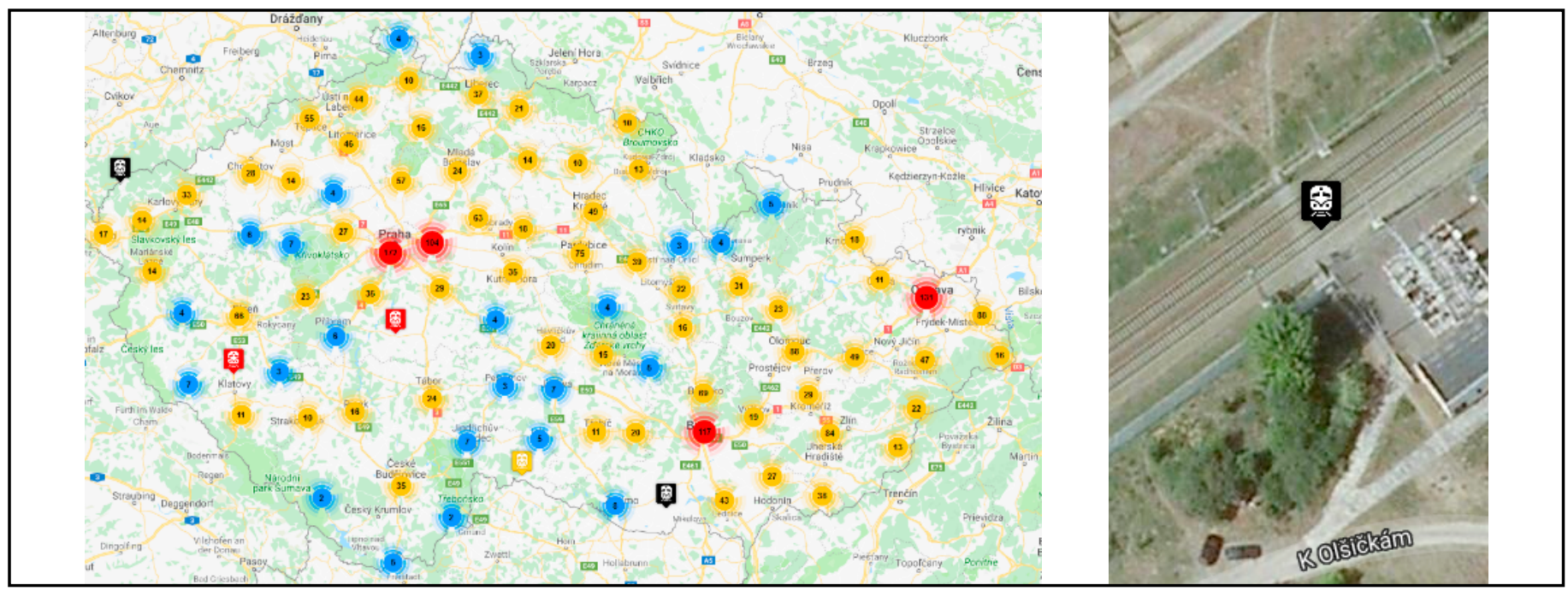

Figure 2. Map of train-person collisions during 2005-2014 (AMELIA); the colored marks show the concentration of accidents in areas (blue-low in values of units, yellow-medium in values of tens, red-high in hundreds). On the right: detail from the map, site of a fatal collision at an illegal shortcut (Rohatec). For more information see http://www.cdvgis. cz/ kubecek/amelia/ 


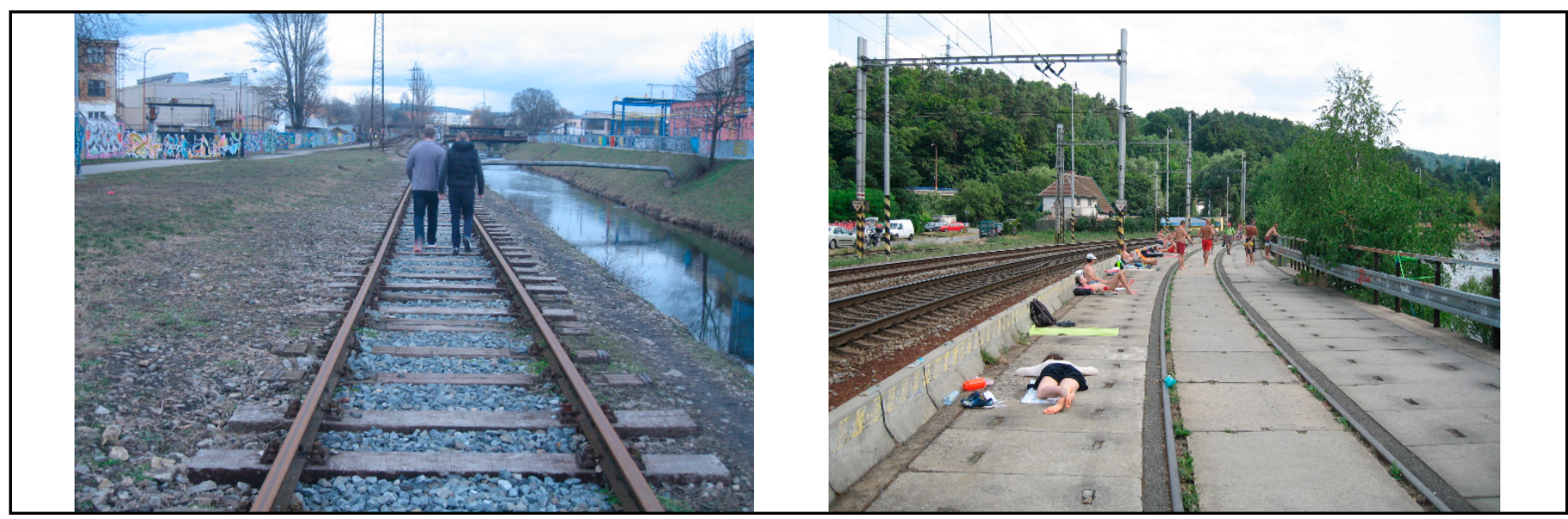

Figure 3. Use of railway infrastructure for recreational purposes

category where trespassing occurs when people cross while the no-crossing signal is operating or bypass the official crossing altogether.

Various mechanisms give rise to high-risk locations. Studies of historic map documents in the NEOS project (Skládaná et al., 2018) demonstrated that the issue of railway trespassing is often closely related to development of the functional use of the land (collective and individual housing, industrial areas, commerce and services, recreational areas, etc.). In the sample of studied locations, there both were places where the railroad had cut through previously existing residential structures and locations where the railway led through originally open landscape and subsequently attracted further urban development with various functional uses. The first type of locations, therefore, represents a situation where the original relationships and connections in the area were substantially disturbed and broken. In cases of the second type of locations, the presence of trespassing is due to insufficiencies in spatial planning, where movement of pedestrians and cyclists was not always taken into account during the formation of urban areas along the railway. This led to the occurrence or underscoring of the railway's barrier effect in the landscape. The abolition of an existing same-level crossing without ensuring an adequate replacement may have similar effects.

The conditions of and motivations for trespassing have been examined also by several foreign studies, and their results correspond to the findings of the Czech projects AMELIA and NEOS. DaSilva (2011) highlights accessibility (insufficiency or lack of fencing, absence of terrain modifications, proximity of a school or other destinations), bad visibility (location behind a curve or a terrain feature not clearly visible from the nearest road), and the possibility for a shortcut to be the main circumstances corresponding to the occurrence of railway trespassing. A Turkish study (Özdogan, 2006) considers the fact that a large number of inhabitants live on the outskirts of big cities in the vicinity of railways without adequate pedestrian infrastructure to be a cause for the occurrence of trespassing and therefore also for the high number of train-person collisions. Trespassing is therefore an everyday and unavoidable occurrence. The phenomenon of railway trespassing also was examined by a Finnish study (Silla, Luoma 2009) in which counting and surveying using questionnaires, among other approaches, was conducted in selected problematic locations with strong occurrence of railway trespassing. At each location, 40 trespassers during the course of a day were recorded, typically adult men. The most frequent motive was shortening a journey. Half of the trespassing respondents stated that they consider their behavior to be safe, and $15 \%$ believed it was in accordance with the law. They considered fences and/or building an underpass to be the most effective measures. A broader survey among inhabitants of a location with frequent occurrence of trespassing (Silla, Luoma 2012) showed that trespassing is generally considered dangerous by $83.5 \%$ of respondents and $81 \%$ considered it illegal, even though $69 \%$ do it themselves.

The precise extent of trespassing is difficult to determine. As reminded by Ian Savage (2007), it is necessary to distinguish between persons who commit railway trespassing and persons who are victims of train-person collisions due to this behavior. The two groups have different characteristics. The total number of trespassers is of course several orders of magnitude greater than is the number of those who are involved in an accident. 
Although the mitigation or complete elimination of trespassing in specific locations is usually a question of urban-planning and construction solutions or the application of technological measures, it also concerns the attitudes and opinions of the public and of potential and current users of illegal shortcuts. Potential information campaigns and educational activities can be a useful accompanying measure. First, however, it is necessary to determine which groups of inhabitants the individual activities should focus upon, what information channels to choose, and what message needs to be delivered to that group - whether it should be the information that trespassing is illegal, information on specific risks of movement in the vicinity of railways, information on the possibilities for being stopped by authorities and fined, appealing for safe behavior, or others. Also in implementing other measures it is beneficial to take into account what the users themselves consider to be effective in dissuading them from crossing the track.

From the results of random questioning at selected illegal shortcuts within the AMELIA project (Skládaná, 2017), it could be expected that (although the issue of trespassing is not systematically solved in the Czech Republic and hardly anybody ever encountered any form of educational activity) the trespassers usually do not act out of lack of knowledge of the law and realize the illegality of entering the track outside of designated areas. At the same time, though, they feel they face no repercussions. Some studies from abroad on related topics have also brought corresponding information (e.g. see above Silla, Luoma 2012). An Australian study focused on pedestrian users of railway crossings (Freeman and Rakotonirainy, 2015, 2017) demonstrated that there are significantly more pedestrians who knowingly violated the regulations than there are of those who did so inadvertently. Respondents who knowingly violated the regulations also knew the risks of entering the crossing when the warning is operating, and considered the presence of police to be the most effective measure

\subsection{Objective and method of the survey}

This article describes the basic findings from a survey of inhabitants living in the vicinity of railways with regard to railway trespassing that was conducted during September 2017. The purpose of the questionnaire survey was to supplement current knowledge of railway trespassing in the Czech Republic with opinions of those more or less directly concerned with trespassing (i.e., people living in the vicinity of some of the many illegal shortcuts or their users themselves). The objective was to acquire information about the knowledge and attitudes of various groups of inhabitants which could be used in designing measures. Specifically, it was investigated to what extent the inhabitants know about an illegal shortcut in their vicinity and use it personally, what circumstances make a case for trespassing, and, on the other hand, what dissuades them from using shortcuts, how they perceive risks, and whether they realize this to be a legal violation. The questionnaire was constructed, consisting of 15 questions, on the basis of knowledge from previous researches (Skládaná, 2017, 2018) and foreign studies (Silla, Luoma 2012).

The survey was conducted with a sample of 619 respondents. Because there is no existing data about the number and structure of the inhabitants who fulfil the difficult-to-define parameter of living "in the vicinity of railways" and moreover the fact that the issue of trespassing is not relevant everywhere, we resigned ourselves to seeking representativeness and the selection was conducted purposefully so that the set would sufficiently represents all age and gender groups. The respondents were questioned by the interviewers in their respective domiciles at 26 selected locations adjacent to existing illegal shortcuts from the category "everyday shortcuts not including stations and stops." The locations were selected so as to include large cities and smaller towns as well as various regions through the Czech Republic regarding the geographical parameters and category of railway. They were located in Brno, Březhrad, Hanušovice, Havlíčkův Brod, Hodonín, Ostrava, Otrokovice, Praha (Prague), Rajhrad u Brna, Rohatec, Svitavy, Tišnov, Třebíč, Třinec, and Zlín.

The questioning was conducted face to face at randomly selected addresses and the answers were recorded into standardized forms. The data was then processed in the statistical program IBM SPSS Statistics. A total of 619 respondents answered the questions, from as young as 12 years of age. Fortyseven percent of the set were male and $53 \%$ were female. Sixteen percent of the respondents had elementary education, $33 \%$ had secondary vocational education, $37 \%$ had secondary school-leaving exam, and $14 \%$ had university education. 
Table 1. Age classification of the data set

\begin{tabular}{lccccc}
\hline Age category & \multicolumn{3}{c}{ Number of respondents } & Share in total & Share within CZ \\
\cline { 2 - 4 } & Total & $M$ & $F$ & & \\
\hline $12-17$ & 31 & 18 & 13 & $5.0 \%$ & $5,3 \%$ \\
$18-29$ & 116 & 67 & 49 & $18.7 \%$ & $13,5 \%$ \\
$30-44$ & 154 & 71 & 83 & $24.9 \%$ & $23,6 \%$ \\
$45-59$ & 131 & 59 & 72 & $21.2 \%$ & $19,3 \%$ \\
60 and more & 187 & 76 & 11 & $30.2 \%$ & $25,5 \%$ \\
\hline
\end{tabular}

One quarter of the sample represents big cities Prague and Brno. There are 4 localities included in Brno an 3 in Prague, both suburbs and areas in inner city. Another big city, Ostrava, creates $9 \%$ of sample with 2 localities in industrial suburbs. Towns of medium size (23000 - 75000 inhabitants) represented by Havlíčkův Brod, Hodonín, Třebíč, Třinec, Zlín and 9 localities make $34 \%$ of sample. The rest of sample (31\%) is created by 8 localities in municipalities and towns up to 18000 inhabitants.

\section{RESULTS}

\subsection{Knowledge of an illegal shortcut}

In total, 512 (83\%) of the respondents were aware of an illegal shortcut in the vicinity of their residences and were acquainted with the rate, purpose, and period of its use, typical users, and highest daily traffic. This data differed substantially at the individual locations, of course, but the entire set was dominated by shortcuts used, as per the respondents' descriptions, frequently, all year round, all through the week, all day long or mostly in the afternoon. The most frequent users are local people generally, pupils and students, or dog owners. The purposes of use are predominantly going to work and to school, to catch a train or bus, taking walks and walking dogs, going to the town/city center, going shopping, and access to garden plots. Although the characteristics of the individual locations are not the subject of this article, they may be used as a guide in determining the causes of and possible solutions for specific high-risk locations (places with high probability of train-person crash). For example, trails which are largely used by inhabitants on their way to their garages (Hodonín, Brno - Holásky) result from gross errors in planning. Places where neighborly relationships are maintained "over the rails" (Hanušovice) are difficult to resolve.

Table 2. Rate of shortcut use

\begin{tabular}{lcc}
\hline Description of shortcut use rate & $\begin{array}{c}\text { Number of } \\
\text { responses }\end{array}$ & $\%$ \\
\hline Individuals per month & 25 & $4.9 \%$ \\
Individuals per week & 56 & $10.9 \%$ \\
Individuals per day & 245 & $47.9 \%$ \\
Dozens per day & 186 & $36.3 \%$ \\
\hline
\end{tabular}

Table 3. Purpose of shortcuts

\begin{tabular}{lcc}
\hline $\begin{array}{l}\text { Description of } \\
\text { shortcut's purpose }\end{array}$ & $\begin{array}{c}\text { Number of } \\
\text { responses }\end{array}$ & $\%$ \\
\hline Way to (from) work & 329 & $64.3 \%{ }^{*}$ \\
Way to (from) school & 215 & $42.0 \%$ \\
To a train, bus & 193 & $37.7 \%$ \\
Walks, walking dogs & 182 & $35.5 \%$ \\
Going shopping & 150 & $29.3 \%$ \\
Going to the town/city center & 147 & $28.7 \%$ \\
Access to garden plots & 118 & $23.0 \%$ \\
Hiking & 94 & $18.4 \%$ \\
Among neighbors & 89 & $17.4 \%$ \\
Access to garages & 67 & $13.1 \%$ \\
$\begin{array}{l}\text { Other (restaurant, cemetery, } \\
\text { hospital, living place for } \\
\text { homeless people and drug } \\
\text { addicts) }\end{array}$ & 15 & $2.9 \%$ \\
\hline
\end{tabular}

* The values do not sum to $100 \%$ because multiple purposes could be selected. 


\section{Table 4. Typical users}

\begin{tabular}{lcc}
\hline Description of shortcut users & $\begin{array}{c}\text { Number of } \\
\text { responses }\end{array}$ & $\%$ \\
\hline Local residents & 291 & $56.8 \%{ }^{*}$ \\
Everyone, no special group & 160 & $31.3 \%$ \\
Dog owners & 82 & $16.0 \%$ \\
Schoolchildren, students, youths & 78 & $15.2 \%$ \\
Hikers, cyclists & 64 & $12.6 \%$ \\
Employees of a specific company & 16 & $3.1 \%$ \\
Other (gardeners, fishermen, & 8 & $1.6 \%$ \\
homeless) & & \\
\hline
\end{tabular}

* The values do not sum to $100 \%$ because multiple user groups could be selected.

Table 5. Seasonality of use

\begin{tabular}{lcc}
\hline $\begin{array}{l}\text { Description as to seasonal use } \\
\text { of shortcut }\end{array}$ & $\begin{array}{l}\text { Number of } \\
\text { responses }\end{array}$ & $\%$ \\
\hline All year round & 453 & $88.5 \%{ }^{*}$ \\
Spring & 37 & $7.2 \%$ \\
Summer & 44 & $8.6 \%$ \\
Autumn & 34 & $6.6 \%$ \\
\hline
\end{tabular}

* The values do not sum to $100 \%$ because if a respondent did not select "all year round" he or she could select more than one season (e.g., spring and summer)

\section{Table 6. Use during the week}

\begin{tabular}{lcc}
\hline $\begin{array}{l}\text { Description of use of shortcut } \\
\text { throughout the week }\end{array}$ & $\begin{array}{l}\text { Number of } \\
\text { responses }\end{array}$ & $\%$ \\
\hline All through the week & 355 & $69.3 \%$ \\
Mainly on workdays & 129 & $25.2 \%$ \\
Mainly on weekend days & 11 & $2.1 \%$ \\
Do not know & 17 & $3.3 \%$ \\
\hline
\end{tabular}

Table 7. Use during the day

\begin{tabular}{lcc}
\hline $\begin{array}{l}\text { Description of use of shortcut } \\
\text { throughout the day }\end{array}$ & $\begin{array}{c}\text { Number of } \\
\text { responses }\end{array}$ & $\%$ \\
\hline All day long & 326 & $63.7 \%$ \\
Mainly in the morning & 42 & $8.2 \%$ \\
Mainly in the afternoon & 82 & $16.0 \%$ \\
Mainly in the evening & 2 & $0.4 \%$ \\
At specific hours & 24 & $4.7 \%$ \\
Do not know & 36 & $7.0 \%$ \\
\hline
\end{tabular}

\subsection{Use of shortcuts by respondents}

A total of 256 (41\%) of respondents use the shortcuts in person, which is exactly one-half of those who know about their existence. The respondents who know about an illegal shortcut and do not use it usually have no reason for using it, and it is not on their way. Less frequently, it is due to the dangerousness of the shortcut. Other reasons (inaccessibility, illegality, fear of being fined, being prohibited by parents, etc.) are mostly isolated.

Half of the users use the shortcut almost daily or at least once a week, 35\% occasionally, and the rest exceptionally. The predominant reason is to shorten a trip and the long distance to an official crossing. Another frequent factor is habit and general conformity ("everyone walks through there"). Thirty-two percent of users feel a certain fear, most frequently that of being hit by a train.

\section{Table 8. Personal use of a shortcut by the respondent}

\begin{tabular}{lccc}
\hline Personally use the shortcut? & Total & Men & Women \\
\hline Yes & 256 & 122 & 134 \\
& $(50 \%)$ & $(50.8 \%)$ & $(49.3 \%)$ \\
No & 256 & 118 & 138 \\
& $(50 \%)$ & $(49.2 \%)$ & $(50.7 \%)$ \\
\hline
\end{tabular}

Table 9. Reasons for not using a shortcut

\begin{tabular}{|c|c|c|c|c|}
\hline $\begin{array}{l}\text { Why to not } \\
\text { use it? }\end{array}$ & Total & Men & Women & Cramer's V \\
\hline $\begin{array}{l}\text { No reason for } \\
\text { using it }\end{array}$ & $\begin{array}{c}190 \\
(74.2 \%)^{*}\end{array}$ & $\begin{array}{c}98 \\
(83.1 \%)\end{array}$ & $\begin{array}{c}92 \\
(66.7 \%)\end{array}$ & 0,187 \\
\hline It is dangerous & $\begin{array}{c}90 \\
(35.2 \%)\end{array}$ & $\begin{array}{c}30 \\
(25.4 \%)\end{array}$ & $\begin{array}{c}60 \\
(43.5 \%)\end{array}$ & 0,188 \\
\hline $\begin{array}{l}\text { It is } \\
\text { inconvenient }\end{array}$ & $\begin{array}{c}19 \\
(7.4 \%)\end{array}$ & $\begin{array}{c}6 \\
(5.1 \%)\end{array}$ & $\begin{array}{c}13 \\
(9.4 \%)\end{array}$ & 0,082 \\
\hline It is forbidden & $\begin{array}{c}23 \\
(9.0 \%)\end{array}$ & $\begin{array}{c}8 \\
(6.8 \%)\end{array}$ & $\begin{array}{c}15 \\
(10.9 \%)\end{array}$ & 0,071 \\
\hline $\begin{array}{l}\text { Other (fine, } \\
\text { prohibition, } \\
\text { baby carriage, } \\
\text { educational } \\
\text { reasons) }\end{array}$ & $\begin{array}{c}17 \\
(6.7 \%)\end{array}$ & $\begin{array}{c}1 \\
(0.8 \%)\end{array}$ & $\begin{array}{c}16 \\
(11.5 \%)\end{array}$ & 0,157 \\
\hline
\end{tabular}

* The values do not sum to $100 \%$ because several reasons could be selected. 
Table 10. Frequency of use of shortcut by the respondent

\begin{tabular}{lccc}
\hline How often do they use it? & Total & Men & Women \\
\hline (Almost) daily & 60 & 25 & 35 \\
& $(23.4 \%)$ & $(20.5 \%)$ & $(26.1 \%)$ \\
At least once a week & 68 & 39 & 29 \\
& $(26.6 \%)$ & $(32.0 \%)$ & $(21.6 \%)$ \\
Occasionally & 90 & 37 & 53 \\
& $(35.2 \%)$ & $(30.3 \%)$ & $(39.6 \%)$ \\
Only exceptionally & 38 & 21 & 17 \\
& $(14.8 \%)$ & $(17.2 \%)$ & $(12.7 \%)$ \\
\hline
\end{tabular}

$N$ of valid cases 256, Cramer's $V=0,151$

Table 11. Reasons for using a shortcut

\begin{tabular}{|c|c|c|c|c|}
\hline Why to use it? & Total & Men & Women & Cramer's V \\
\hline $\begin{array}{l}\text { Shortening } \\
\text { a trip }\end{array}$ & $\begin{array}{c}217 \\
(84.8 \%)\end{array}$ & $\begin{array}{c}101 \\
(82.8 \%)\end{array}$ & $\begin{array}{c}116 \\
(86.6 \%)\end{array}$ & 0,053 \\
\hline Habit & $\begin{array}{c}63 \\
(24.6 \%)\end{array}$ & $\begin{array}{c}31 \\
(25.4 \%)\end{array}$ & $\begin{array}{c}32 \\
(23.9 \%)\end{array}$ & 0,018 \\
\hline $\begin{array}{l}\text { Everyone } \\
\text { goes through } \\
\text { there }\end{array}$ & $\begin{array}{c}41 \\
(16.0 \%)\end{array}$ & $\begin{array}{c}17 \\
(13.9 \%)\end{array}$ & $\begin{array}{c}24 \\
(17.9 \%)\end{array}$ & 0,054 \\
\hline $\begin{array}{l}\text { An official } \\
\text { crossing is } \\
\text { far away, } \\
\text { inconvenient, } \\
\text { or dangerous }\end{array}$ & $\begin{array}{c}65 \\
(25.4 \%)\end{array}$ & $\begin{array}{c}30 \\
(24.6 \%)\end{array}$ & $\begin{array}{c}35 \\
(26.2 \%)\end{array}$ & 0,010 \\
\hline $\begin{array}{l}\text { Other (only } \\
\text { access, } \\
\text { duration } \\
\text { of crossing } \\
\text { warning, } \\
\text { nostalgia, } \\
\text { ease, hiking, } \\
\text { favoring } \\
\text { footpaths) }\end{array}$ & $\begin{array}{c}10 \\
(3.9 \%)\end{array}$ & $\begin{array}{c}6 \\
(4.9 \%)\end{array}$ & $\begin{array}{c}6 \\
(4.5 \%)\end{array}$ & 0,010 \\
\hline
\end{tabular}

* The values do not sum to $100 \%$ because several reasons could be selected.

Table 12. Fears during crossing

\begin{tabular}{lccc}
\hline Do they fear crossing? & Total & Men & Women \\
\hline I do have fear & 81 & 25 & 56 \\
& $(31.6 \%)$ & $(20.5 \%)$ & $(41.8 \%)$ \\
I do not have fear & 175 & 97 & 78 \\
& $(68.4 \%)$ & $(79.5 \%)$ & $(58.2 \%)$ \\
\hline
\end{tabular}

$N$ of valid cases 256, Cramer's $V=0,260$
Table 13. Reason for fears

\begin{tabular}{lccc}
\hline Reason for fears & Total & Men & Women \\
\hline Fear of accident & 64 & 17 & 47 \\
& $(79.0 \%)$ & $(68.0 \%)$ & $(83.9 \%)$ \\
Fear of fine & 12 & 6 & 6 \\
& $(14.8 \%)$ & $(24.0 \%)$ & $(10.7 \%)$ \\
Fear of police, camera, & 5 & 2 & 3 \\
close persons & $(6.2 \%)$ & $(8.0 \%)$ & $(5.4 \%)$ \\
\hline Nof valid cases 81, Cramer's $V=0,274$ & &
\end{tabular}

The results indicate that men use illegal shortcuts as much as women do (Table 8). There are certain differences between age categories, but not statistically significant.

Motivations to use shortcuts (Table 11) do not differ much among groups. Only the stronger representation of the group conformity factor ("everyone goes through there") in the youngest category is noteworthy, though not statistically significant. In contrast, more differences between genders and age categories can be found in reasons for not using shortcuts (Table 9). Whereas for men it is mostly about not needing to go through the illegal shortcut, for women there is a stronger application of other factors, especially fears of an accident but also because trespassing is illegal and one could be fined (Table 9). Younger people who do not use the shortcut (12-17 and 18-29 years) more frequently (90\%) state the absence of reason to do so more than do people in other categories (69\%). On the other hand, the younger groups substantially less frequently admit that trespassing seems dangerous $(15 \%$ of respondents up to 30 years of age and $42 \%$ of older ones) and inconvenience plays a slightly smaller role in youths. There were also 4 respondents who stated that they are forbidden from using the shortcut. Surprisingly they were not among the youngest category but among the eldest.

Fear of crossing is significantly more frequently admitted by women than by men (Table 12). No one from the 12-17 years category had such fears, and only $18 \%$ within the 18-29 year category did. Fear is most frequently felt by users older than 60 years of age (46\%), with women a bit more frequently fearing collision during crossing, whereas men feared police and fines.

\subsection{General knowledge}

In the last part of the interview, all respondents, including those who did not know shortcuts in their vi- 
cinity, had the opportunity to express their approval or disapproval with certain statements concerning movement on the railway (Table 14). Responses suggested a given uncertainty in the matter as to the legality of moving on the railway. Even though $82 \%$ of respondents correctly agree with the statement that crossing railways other than at official crossings is illegal and only $18 \%$ disagree with this statement, $28 \%$ of the respondents believe that one essentially may cross the railway except for places where the prohibition is explicitly stated on a sign or where there is a fence.

Attitudes concerning questions of safety of crossing are also ambiguous. Even though the respondents agreed that crossing outside of official paths is dangerous (86\%), 54\% of the respondents believed that it was safe to cross a railroad if they look around well first. Seventy-one percent of respondents hold the increasingly less justified belief that a train is easy to hear from "far away".

\section{Table 14. Rate of agreement with statements}

\begin{tabular}{lc}
\hline Statement & Total agree \\
\hline "Crossing railways other than at official & 532 \\
crossings is dangerous." & $(85.9 \%)$ \\
"Crossing railways other than at official & 505 \\
crossings is a legal violation." & $(81.6 \%)$ \\
"A train is easy to hear from far away." & 437 \\
& $(70.6 \%)$ \\
"If I look around sufficiently and see that no & 336 \\
train is coming, it is safe to cross the railway.” & $(54.3 \%)$ \\
"A pedestrian may cross a railway at any place & 174 \\
except for places with fences or with signs & $(28.1 \%)$ \\
prohibiting it." & \\
\hline
\end{tabular}

\section{Table 15. Estimate of the number of victims for 2016}

\begin{tabular}{cc}
\hline $\begin{array}{l}\text { How many people died after } \\
\text { a train-person collision in 2016? }\end{array}$ & Total \\
\hline 46 & $145(23.4 \%)$ \\
98 & $181(29.2 \%)$ \\
191 & $165(26.7 \%)$ \\
479 & $94(15.2 \%)$ \\
832 & $25(4.0 \%)$ \\
1417 & $9(1.5 \%)$ \\
\hline
\end{tabular}

The estimate as to the number of train-person collision victims (6 categories, of which "191" was real number, were given by the questionnaire and each respondent chose one of them) for the past year shows that people rather tend to underestimate the consequences of trespassing.

Concerning general knowledge and estimation of number of victims (tables 14 and 15), a respondent's gender does not play much of a role; women are slightly more inclined to recognize risks, but the differences are not crucial. There are also certain differences among age categories; although not significant, the differences should be taken into account when possibly formulating educational measures. Among the youngest (12-17 years), only 19\% stated that one may cross at any place apart from fenced or expressly marked places. In other categories, the proportion of incorrect answers was higher: among respondents aged 18-29 and over 60 years of age it even exceeded $30 \%$. This category had also ca $10 \%$ smaller share of those who believed that a good look around ensures a safe crossing compared to others. On the other hand, the youngest were the most frequent to state $(81 \%)$ that a train is easily heard from afar. Here, we can believe this was due to a lack of experience rather than their having more acute senses.

As shown by the analysis of opinions and behaviors of respondents who are aware of a shortcut in their vicinity, general attitudes and knowledge of risks substantially correspond with behavior (Table 16). Among respondents who believe they may cross wherever there is no fence or sign, 74\% use a shortcut, as opposed to only $40 \%$ of those who disagree with that statement. Among those who believe that crossing a railway other than at official crossings is dangerous, only $45 \%$ use a shortcut, as opposed to $80 \%$ of those who disagree; and the most important factor seems to be the perception of safety when behaving carefully.

Table 16. Use of a shortcut according to agreement or disagreement with statements (only in the group of those who know about a shortcut; $n=512$ )

\begin{tabular}{|c|c|c|c|}
\hline & & $\begin{array}{l}\text { Share of } \\
\text { respondents } \\
\text { who use } \\
\text { a shortcut }\end{array}$ & Cramer's V \\
\hline $\begin{array}{l}\text { "A pedestrian may } \\
\text { cross a railway at } \\
\text { any place except } \\
\text { for places with } \\
\text { fences or with signs } \\
\text { prohibiting it." }\end{array}$ & $\begin{array}{l}\text { Agree } \\
\text { Disagree }\end{array}$ & $\begin{array}{l}74 \% \\
40 \%\end{array}$ & 0,302 \\
\hline
\end{tabular}




\begin{tabular}{|c|c|c|c|}
\hline \multirow{2}{*}{$\begin{array}{l}\text { "Crossing railways } \\
\text { other than at } \\
\text { official crossings is } \\
\text { a legal violation." }\end{array}$} & Agree & $46 \%$ & \multirow[t]{2}{*}{0,183} \\
\hline & Disagree & $69 \%$ & \\
\hline \multirow{2}{*}{$\begin{array}{l}\text { "Crossing railways } \\
\text { other than at } \\
\text { official crossings is } \\
\text { dangerous." }\end{array}$} & Agree & $45 \%$ & \multirow[t]{2}{*}{0,249} \\
\hline & Disagree & $80 \%$ & \\
\hline \multirow{2}{*}{$\begin{array}{l}\text { "If I look around } \\
\text { sufficiently and } \\
\text { see that no train is } \\
\text { coming, it is safe to } \\
\text { cross the railway." }\end{array}$} & Agree & $75 \%$ & \multirow[t]{2}{*}{0,577} \\
\hline & Disagree & $16 \%$ & \\
\hline \multirow{2}{*}{$\begin{array}{l}\text { "A train is easy } \\
\text { to hear from far } \\
\text { away." }\end{array}$} & Agree & $56 \%$ & \multirow[t]{2}{*}{0,190} \\
\hline & Disagree & $35 \%$ & \\
\hline
\end{tabular}

\section{CONCLUSION}

The survey provides information about the knowledge, behavior, and attitudes of inhabitants living in the vicinity of selected illegal shortcuts, as well as information on the basic characteristics of railway trespassing in the selected locations. The features of individual locations differed, but the knowledge, opinions, fears and declared behavior of the respondents repeated through the whole file; it can be assumed that these results can be generalized for all areas located in the vicinity of railway in $\mathrm{CZ}$.

A large part (83\%) of those questioned knew about unofficial paths crossing the railway and $41 \%$ stated that they used them. In comparison with a similar foreign survey (Silla, Luoma 2012), trespassing in Czech conditions obviously differs in that there is less gender imbalance. Whereas in the Finnish survey, $73 \%$ of the surveyed men and $64 \%$ of the women were using shortcuts, in our survey the proportions of female and male users were practically identical (onehalf of those who knew about the shortcut). In contrast to the Finnish research, a lower representation of trespassers among the older age groups was not detected. The proportions of respondents who generally consider trespassing to be dangerous and illegal were similar in both studies.

The results of the research have suggested how the behaviors, attitudes, and knowledge differ by age and gender. Even though the proportion of women entering the railway is the same as for men, women are more aware of the risks and illegality of trespassing. Fear of accident or of being stopped by police also are more frequent reasons to avoid trespass- ing for women than for men. Even though younger respondents generally have good knowledge, those who use illegal shortcuts less frequently admit risks than do older ones. For young people, the group conformity factor also needs to be accounted for, and it is necessary to focus any potential measures also on their ability to deal with peer pressure. The relationship between the level of educational attainment and the evaluated characteristics was not significant.

The finding that almost $30 \%$ of the respondents consider crossing the railway anywhere where there is no warning sign or fence to be legal is important for formulating awareness-raising and educational measures. There is also a prevailing stereotypical image of a train as being a noisy and slow vehicle that a person crossing can hear and see in time. The survey, however, confirmed a strong connection between attitudes and behaviors. It can therefore be presumed that correctly targeted and implemented educational measures and campaigns will make sense. The first move to the survey results application was already made: two short educational films for children and students were produced, aimed not only to knowledge, but also to motivation not to risk.

On the other hand, it should be also reminded that for $84.8 \%$ of respondents, the illegal crossing means more or less substantial shortcut compared to legal way, and $25.4 \%$ of respondents use the illegal shortcut because of inconvenience or even dangerousness of the official crossing. Educational measures are practically uneffective, wherever legal pedestrian infrastructure is unsuitably located, poorly illuminated, passable with difficulties, or missing at all. The physical conditions and pedestrian links in concrete location must be first assessed, and public education incorporated into the complex of measures.

Acknowledgements: This article was created with the financial support of the Ministry of Education, Youth, and Sports within the National Programme of Sustainability I, project of Transport R\&D Centre (LO1610) on the research infrastructure acquired from the Operation Programme Research and Development for Innovations (CZ.1.05/2.1.00/03.0064).

\section{REFERENCES}

daSilva MP (2011) Railroad Infrastructure Trespass Detection Performance Guidelines, Final report No. DOT/FRA/ORD11/01a. Federal Railroad Administration 
Freeman, J. \& Rakotonirainy, A. (2015). Mistakes or deliberate violations? A study into the origins of rule breaking at pedestrian train crossings. Accident Analysis \& Prevention, 77, 45-50. http://dx.doi.org/10.1016/j.aap.2015.01.015

Freeman, J. \& Rakotonirainy, A. (2017). Can rail pedestrian violations be deterred? An investigation into the threat of legal and non-legal sanctions. Transportation Research Part F: Traffic Psychology and Behaviour, 45, 102-109. http://dx.doi. org/10.1016/j.trf.2016.11.016

Hoekstra, T. \& Wegman, F. (2011). Improving the effectiveness of road safety campaigns: Current and new practices. IATSS Research, 34(2), 80-86. http://dx.doi.org/10.1016/j. iatssr.2011.01.003

Lobb, B. (2006). Trespassing on the tracks: A review of railway pedestrian safety research. Journal of Safety Research, 37(4), 359-365. doi:10.1016/j.jsr.2006.04.005

Özdogan M., Cakar S., Ağalar F., Eryilmaz M., Aytaç B., Aydinuraz K. (2006) The epidemiology of the railway related casualties. Turkish Journal of Trauma and Emergency Surgery, 12, 235-241

Rail Safety Inspection Office, http://www.dicr.cz

Savage, I. (2007). Trespassing on the railroad. Research in Transportation Economics, 20, 199-224. http://ageconsearch. umn.edu/bitstream/207946/2/2006_1A_TrespassRail_paper.pdf

Silla, A. \& Luoma, J. (2009). Trespassing on Finnish railways: Identification of problem sites and characteristics of trespassing behaviour. European Transport Research Review, 1(1), 47-53. doi:10.1007/s12544-008-0005-y

Silla, A. \& Luoma, J. (2012). Opinions on railway trespassing of people living close to a railway line. Safety Science, 50(1), 62-67. http://dx.doi.org/10.1016/j.ssci.2011.07.002

Skládaná, P. et al. (2017), AMELIA - Výzkum podmínek a návrh opatření pro omezení počtu a zmírnění následků neoprávněných vstupů chodců do prostoru dráhy [Research of conditions and proposal for measures to limit the consequences of railway trespassing]. Retrieved from https://amelia.cdvinfo.cz/

Skládaná, P., Havlíček, M., Dostál, I., Skládaný, P., Tučka, P., Perůtka, J. (2018), Land Use as a Motivation for Railway Trespassing: Experience from the Czech Republic. Land 2018, 7(1), 1; https://doi.org/10.3390/land7010001 